\title{
CHANGING THE PERSPECTIVE ON SPECIALIZED KNOWLEDGE IN NURSING: AN EPISTEMOLOGICAL DEBATE
}

Rafael Celestino da Silva ${ }^{1}$ Márcia de Assunção Ferreira²

Silva RC, Ferreira MA. Changing the perspective on specialized knowledge in nursing: an epistemological debate. Rev Latino-am Enfermagem 2008 novembro-dezembro; 16(6):1042-8.

This theoretical study results from the observation and problematization of inexperienced nurses' insertion in technological environments, which requires specialized knowledge and practices. We pose the question if the use of this knowledge leads to a fragmented practice. The objective is to discuss the specialized knowledge necessary for nursing work in this setting, at the light of the principles that guide the new scientific paradigm. A bibliographical survey and literature review were carried out. The discussion is based on the assertion that, although specialized knowledge originates in a reductionist, objective, rational and mechanistic paradigm, its application in specialized nursing practice is not necessarily based on these principles, but on the scientific paradigm that guides them as individuals in the world. This suggests a change in the perspective on this issue.

DESCRIPTORS: biomedical technology; nursing care. nursing; intensive care units; specialties nursing

\section{UNA NUEVA PERSPECTIVA SOBRE EL CONOCIMIENTO ESPECIALIZADO EN ENFERMERÍA: UN DEBATE EPISTEMOLÓGICO}

Se trata de un estudio de naturaleza teórica originado a la observación y problematización de la inserción de enfermeros novatos en ambientes tecnológicos, los cuales presuponen la necesidad de conocimientos/prácticas especializados. Se cuestiona si la utilización de este conocimiento presupone una práctica fragmentada. Se objetiva discutir el conocimiento especializado necesario para la actuación del enfermero en estos escenarios a la luz de los principios orientadores del nuevo paradigma de la ciencia. A través del levantamiento bibliográfico y la revisión de literatura, se construye la discusión en la defensa de que, a pesar de que el conocimiento especializado se origine de un paradigma reduccionista, objetivo, racional y mecanicista, su aplicación en la práctica especializada del enfermero no se guía necesariamente por estos principios; lo hace más bien con el paradigma de la ciencia que orienta el sujeto en el mundo, sugerido así una nueva perspectiva sobre esta cuestión.

DESCRIPTORES: tecnología biomédica; cuidados de enfermería; enfermería; unidades de terapia intensiva; especialidades de enfermería

\section{UM DESLOCAMENTO DO OLHAR SOBRE O CONHECIMENTO ESPECIALIZADO EM ENFERMAGEM: DEBATE EPISTEMOLÓGICO}

Estudo de natureza teórica, originado da observação e problematização da inserção de enfermeiros novatos em ambientes tecnológicos, os quais pressupõem a necessidade de saber/prática especializada. Questiona-se se a utilização desse saber pressupõe prática fragmentada. Objetiva-se discutir o conhecimento especializado necessário para atuação do enfermeiro nesses cenários, à luz dos princípios norteadores do novo paradigma da ciência. Através do levantamento bibliográfico e revisão de literatura, construiu-se a discussão na defesa de que, embora o conhecimento especializado se origine de paradigma reducionista, objetivo, racional e mecanicista, a sua aplicação na prática especializada do enfermeiro não se pauta necessariamente nesses princípios, mas no paradigma da ciência que o orienta, enquanto sujeito no mundo, sugerindo assim, deslocamento do olhar sobre essa questão.

DESCRITORES: tecnologia biomédica; cuidados de enfermagem; enfermagem; unidades de terapia intensiva; especialidades de enfermagem

Escola de Enfermagem Anna Nery da Universidade Federal do Rio de Janeiro, Brazil:

${ }^{1}$ RN, Master's student, e-mail: rafaenfer@yahoo.com.br; ${ }^{2}$ Ph.D. in Nursing, Full Professor, e-mail: marciadeaf@ibest.com.br. 


\section{SOME INITIAL CONSIDERATIONS}

Introduction and spread of Intensive Care Units (ICU) in Brazil took place especially in the 70's in the 20th century, creating the need for specialized personnel that were familiar with the equipment present in these units, as well as the diseases usually presented by in-patients, which helped design the theory of nursing in this area.

Considering that professionals working in this setting are quickly outdated, work at ICU has been characterized over time by the use of specific knowledge and constant improvement and training for acquiring the knowledge that meets the speed of the new technologies. As a result of this fast incorporation of new knowledge to care in intensive care, nurses had to be trained and be able to deal with all stages of work, to provide total and quality care.

In this sense, it is important to know peculiarities in ICU care which encompasses the use of equipment, material, and patients who present different needs from those in other hospital wards. The great presence of equipment and technological processes influence all those working in this environment. For that reason, to reflect on the impact of technology in the practice is essential ${ }^{(1)}$.

Technological development observed at ICU makes nurses working in it follow this evolvement, taking up new responsibilities. Thus, these nurses have to be prepared to deal with this specialized patients and environment.

Specialization of knowledge and care are a reality backed by quick development and opening of new action and research fields. There are many challenges in it, one of them is the current curricular programs and care models which graduate General Nurses considered as the principles and guidelines of the National Health System; the other refers to the distribution of nurses among hospital sectors, since it is common to find specialized care centers with nurses that, for several management issues, were transferred to sectors they had little or no experience in or they were not part of their professional interests. Therefore, several settings of technological, specialized, care received inexperienced nurses with non-specialized professional education.

The discussion in this article was made by observing the insertion of these new nurses in technological environments where there should be a specialized knowledge/practice. In view of this, the following question was posed: Specialized knowledge/ practice, needed for nursing work in technological environment from the biomedical paradigm assumes fragmented knowledge/practice? To answer this question, the survey aimed at reaching the following goals: to discuss the insertion of new nurses in technological environment, with issues regarding knowledge specialization; and to discuss specialized knowledge at the light of the principles guiding the new science paradigm.

To reach these goals, we have looked for studies that dealt with the specificity in technological environments, and the principles guiding science paradigms. From the analysis of the content of these studies, the material which enabled to build up this article into three parts was extracted in order to adhere to the discussion proposed, they were: the first part presents the central theme in the practical field, where the insertion of new nurses is correlated with the specificity of care in technological environments; the second aims at redirecting, based on the principles of science paradigms, the way specialized knowledge in nursing is assessed; and in the third part we identify the elements backing up the proposal of displacing the look on specialized knowledge in nursing.

\section{THE DEBATE ON THE PRACTICAL FIELD: NEW NURSES AND TECHNOLOGICAL CARE AND THE NEED FOR SPECIALIZED KNOWLEDGE}

In the process of forming nursing teams that will take care of high-complexity patients, it is essential to consider aspects regarding professional history, previous experience, and specific skills of professionals. This process demands a different look on the technical scientific preparation of nurses so that care given meets the demands of clients in all dimensions.

Empirical observations of care practice corroborated by the nursing literature identify the fact that working for a long time in a certain sector does not guarantee that nurses will stay in the same sector, since different criteria guide allocation of nursing personnel at hospitals. In this sense, knowledge, 
experiences, and preferences of professionals are not always considered ${ }^{(2)}$.

Most of the times, public tests do not take into account experiences and expertise of nurses, they do not even raise their expectations. Because of that, several teams are made up by new nurses, especially in sectors of intensive and high complexity care. Reflecting on this issue is necessary, because it has outcomes in the nursing care to patients.

Knowledge is related with experience which will lead to proficiency, that is, intellectual and scientific authority results from the association between practical and theoretical knowledge, that classify professionals into five performance levels: novice or beginner, advanced beginner, competent, proficient and expert ${ }^{(3)}$.

Expert nurses are those with great experience, or background. This basic requirement makes them have intuitive awareness and they do not waste time with wrong diagnoses and unfruitful behavior, since they develop, test and refine their propositions and principles based on practical situations. Thus, experts have a better view of the situation, which enable them to solve problems in a different manner from novices, and the experience makes them solve the problem more efficiently ${ }^{(3)}$.

Novice or beginners are those who still do not master the necessary tools for care of certain patients, even though they have experience in other areas, and they are guided only for punctual activities. Because they lack experience, they receive steps to follow to perform their activities, to serve as facilitators for actions. However, these steps may act against performance since they mandate decision making in face of a real situation ${ }^{(3)}$.

For novice nurses, each situation is new and strange, in dealing with patients in critical states, results may be irreversible. Novices have feelings, frustrations, and expectations that sometimes are not seen in objective observation; however, they interfere in the way they act, think, and react to daily situations. A space is needed for them to discuss the practice, its limits and difficulties ${ }^{(4)}$.

It is also essential to consider the complexity involved in this care, since the speed in which technological changes occur is amazing, made evident, specially, by the incorporation of new concepts and resources to improve care. This brings positive advances and challenges to professional work since, in addition to direct care; it is also essential to understand how equipment works and interpret data observed to guarantee reliability of results ${ }^{(5)}$.

Therefore, incorporating technology in health care brought about results to nursing that go from changes in the way care is processed to resetting relations established by individuals, caused by changes in roles and work standards.

In this sense, the possible difficulties faced by novice nurses taking care of these patients must be pondered, to use technological resources to identify the needs requiring nursing care. So, event though society is going toward polyvalent and multifunctional professionals, we understand that specialized nurses meet the demands of a market that is increasingly requiring more specific and updated knowledge, especially in the fields of advanced technology. This must be based on the understanding that human beings are unique and must be cared for in this way ${ }^{(6)}$. However, there are nurses who are still against specialization of knowledge basing themselves on the discourse that professionals are focusing on the part and missing the view of the whole.

Insertion of novice nurses in ICU shows the importance of specialized education. However, to be specialized in a certain field does not represent reducing knowledge if the proposal is for a new reading of specialization at the light of a new theoretical assumption.

\section{THE DEBATE IN THE THEORETICAL FIELD: SCIENCE PARADIGMS AND THEIR INTERFACES WITH SPECIALIZED KNOWLEDGE}

The mechanistic view of the world starts as a paradigm in the 15th century, suggesting that nature can be controlled, mastered, and described numerically. Human science is developed at the light of Descartes" ideas that strengthens the belief in the certainty of scientific knowledge, with the mind being privileged over matter, characterizing the mind-body dualism ${ }^{(7)}$. A totalitarian model is set, denying the rational feature of all forms of knowledge that are not based on the epistemology and method of scientific rationality.

In modern science, knowing means to quantify. Features of the object that could not be 
measured are excluded from the analysis, thus, scientific rigor is assessed by the rigor in measurements. Subjectivity is not considered and the interference of humane and religious values in the production of knowledge is not tolerated. The Cartesian scientific method reduces complexity. In this sense knowing means to share and classify and then to relate what was separated ${ }^{(7)}$.

This model has, as one of its rules, the division of the whole into increasingly smaller parts so that they can be studied separately, in an isolated fashion ${ }^{(8)}$. This rule applied to knowledge, more frequently to the health field, supports specializations.

In this sense, knowledge develops with specialization, and the more restricted the object it deals with, the more strict knowledge is. This thinking model in which specialization is based can be seen in several fields of knowledge, especially in the medical one, and it contributes to a fragmented model of specialization, with the approach focusing on isolated systems and organs of the body as a whole. Thus, the idea of the expert - that person mastering a part of the whole - became valued in the society, with consequences on the way nursing knowledge was organized.

The development and deepening of knowing enabled by these conceptions allowed to identify the fragility of the principles in which it is based, as well as their limits, and structural problems that contribute to the crisis of this paradigm, backed up especially by theoretical conditions such as quantum mechanics. The new Physics came to demonstrate that it is impossible to measure and object without interfering in it, changing it to such an extent that it leaves the process as a different object ${ }^{(9)}$. This led to the insertion of subjectivity in the production of knowledge, bringing about the principles of a new paradigm to the discussion in science.

Holism became one of the emerging paradigms that opposes to the separability determined by fragmentation of things. It is formed by principles, ways of thinking and behave in face of situations, people and objects that are presented in our daily lives, and it points out to a multidisciplinary structure of knowledge enabling greater understanding of phenomena. Holistic thinking assumes the idea of set and totality of all things of the biological domain, as well as it extends to the highest signs of the human spirit, that is, there is reciprocity between the parts forming the whole ${ }^{(10)}$.
This new awareness results from a revolution in thinking, that changes the prevalence of the formal logical thinking as the only resource in knowledge production, and it opposes itself to the conflicts between body, emotions, and mind, and these conflicts result from the fragmented understanding of matter, life, mind, and personality within the dominant paradigm of science (Cartesian) ${ }^{(10)}$.

These ideological trends and their philosophical assumptions influenced the way professional nursing started and organized itself, as well as the way knowledge was built. Thus, development of nursing specialties has a close relationship with the history of the profession which, in turn, carries the marks of the paradigms that lead thinking and actions of mankind.

Thus, it is necessary to understand hoe knowledge in nursing was developed, to understand which situations favored specialties in nursing, and try to explain the guiding principles of the specialized professional practice, that was the bases for the specialization of knowing in nursing and that, in theory, would be the drive of the caring model of specialized nurses.

Knowledge in nursing and its closeness with scientific paradigms

Professional Nursing starts from the Nightingale system, in a time where the biomedical model of care was at a high. Based on the positivist paradigm of science, the health model deriving from it had results in the conception of body as a machine, the organs its gear, the disease a fault and, opposed to that, health was the absence of diseases. This conception of disease as faults in parts of the human machine leads to a rigorous dichotomy between body and mind, and induces to the need for increasingly specialized professionals to treat each part of the human body ${ }^{(11)}$.

However, the theoretical framework guiding nursing practice idealized by Florence Nightingale values the conception of the totality of human beings and this is marked in her care philosophy, that are close to Hippocrates principles that sustains health as a state of harmony of men and nature. Health, then, results from the balance between the different components of the body with the environment, that is, health and disease depend on the perfect integration between mind, body, and environment. 
Although modern Nursing has started following the dominant ideology, that is, a biological, scientific, and rational, nursing was organized around a theoretical and scientific project based on a new perspective.

The term nursing science started to be used in the 50's, in the 20th century, demonstrating the need to build and consolidate a body of specific knowledge for nursing ${ }^{(12)}$. In an attempt to correspond to the dominating model and to pursuit science, nursing used knowledge from other areas, especially biomedical. With this approximation, it assumed the philosophical assumptions that support it, based on objectivity of knowledge. These assumptions, together with the increasing technological incorporation in the health area and the consequent complexity of the places for professional work, lead to the appearance and spread of specialties in nursing. Thus, the dominant paradigm is part of the intellectual context that guides specialized knowledge in nursing, with influence in the thinking and action of nurse professionals.

However, specialization of health professionals nowadays is a fact, which makes what was learned in the beginning of education insignificant due to the new demands of clients. So, for professionals to perform their work in full, they have to increase and deepen their knowing in a specific area. Therefore, the specialization process of knowledge and its consequent demands for the work field seems to be irreversible; however, we have to think about that in the light of a new logic, and not only according to the logics that led to the movement for specialization.

Deepening knowing is necessary for nurses to get closer to those requiring care, so that professionals make decisions on actions (care) based on the principles that sustain it. The level of consistency of the knowledge is one of the determining factors that will make patients welcome nurses, if they feel safe because of the confidence showed by them, they will let their body be treated by them. The objective of scientific knowledge is care, either general or specialized, enabling effective interaction, since the experience and knowledge can be seen as ways to get closer to those we care for.

This discussion points out the importance of redirecting the analysis of specialized knowledge in nursing to understand that, although it comes from ideas of the dominant paradigm in science, its application in the practice can be made in a way to enable the performance of a holistic care. We defend this kind of care because it recommends the necessary care for individuals and not for the parts of their bodies. In this sense, clients are included in the process as transforming agents of the reality and builders of knowledge, rather than passive to it. In the consideration that the principles of nursing care, according to the Nightingale discourse, are based on integrated and contextual knowledge of human beings, we must not understand them and their body in a fragmented way.

\section{THE DEBATE ON SPECIALIZED KNOWLEDGE: DISPLACING THE LOOK}

The excessive division into parts of the scientific knowledge makes scientists neglect other aspects that are around specialized knowledge, leading to negative effects regarding the production and use of this knowing(7). Overall, when we try to change these features they end up being reproduced in another way. This is because, we admit there is no solution to this problem within the dominant paradigm, showing that the later is the real problem that leads to the assumptions where all the rest come from. In this sense, the present discussion is driven to a new understanding of specialization under a new conceptual view, from the understanding that knowledge is total, but as total, it is also local ${ }^{(7)}$. That is, it is formed around issues that meet one another and suggest a complementarity of knowing. Thus, we aim at overcoming the classic model, using as a reference the understanding that, although development in knowledge is more appropriate by the division of the object into parts, this same perception shows that you cannot reduce the total into the parts that form it, running the risk of producing distorted knowledge that does not correspond to the reality.

Thus, when we consider total knowledge in the current days, we put people as authors and subjects in the world, in the center of knowledge, therefore acknowledging that social phenomena are historically conditioned and culturally determined; social sciences cannot produce trustworthy predictions because human beings change their behavior as they 
acquire knowledge; social phenomena are subjective in nature and are not influenced by the objectivity of behavior; when observing, social scientists are not free from the values of their practice in general and, therefore, also of their practice as scientists ${ }^{(7)}$.

Thus, we understand that human behavior cannot be described and explained only based on their exterior and objective features, since the same act can correspond to different action senses. Social phenomena must be understood from the mental attitudes and sense that agents give to actions.

Therefore, when we bring to discussion specialized knowledge in the view of this discussion, particularly in the area of nursing, it is clear that, although originally it started as education that is fragmented in the beginning, specialization of knowledge is a current need that is not necessarily a fragmented care.

This is because, in the light of social constructionist conception of knowledge and a theoretical paradigm of psychosociological bases, we understand that the way individuals conceive the phenomena that occur in their life will determine the way they will guide their behavior. That is, the view of the world of individuals, their path and life experiences, the sense they give to things are the aspects to be considered when we look for justifications for a perspective of action/care that is integrative or fragmented.

The way nurses, experts or not, think of people, objects and situations they face in their daily lives as well as the meaning they give to them will indicate the principles guiding the way they act. Knowledge, then, is part of nurses and the profession, and deepening it, either the theoretical or practical knowledge is one of the principles for total and quality care.

\section{SOME FINAL CONSIDERATIONS}

What was presented up to the moment make us reflect on the nursing care that have been performed by novice nurses, that are directly related with survival and rehabilitation of clients and quality of care.

In the discussion proposed, the client is considered as subject, technology is a complement, and care is a therapeutic action. This specifies the need for a professional with technical and scientific competence to develop it and a commitment and ethics with the agents interacting among each other. Currently, issues related to professional actions, quality of services and citizenship are in the agenda of discussions; therefore, it is timely to reflect critically on the insertion ways of novice nurses in intensive care sectors. Not to resist them but to reinforce the importance of professional qualification and specialized education that will have direct impact on the quality of care and indirect impact on professional status, adding value to the profession.

Thus, the relationship between professionals and clients is complex and cannot be reduced, neither in its relationship aspect nor in its technical aspect. The conception of care that considers individuals in their multiple dimension, and that uses the senses in the search for important information must be valued, but, at the same time, it is extremely important to apply a well based technical scientific knowledge and the presence of a well prepared professional, especially in settings of state of the art technology, fostering balance between expressive and technical/ technological care.

Therefore, it is necessary a deep reflection on the professional specialization to work in highly specialized and technological sectors, understanding them as one of the instruments for care in nursing in the integrating perspective. This is because to defend valuing totality of beings in the process of health care, professionals must have technical and relational competence to perform it. So, deepened knowing from specialization that enables to form a confident and autonomous professional is one of the pillars that allowed for this care with a holistic view to take place.

Last, we defend that the attitude of nurses with clients, regardless of the working scenario and professional qualification, is determined especially by the way they mean, perceive, and conceive things from their daily lives which will provide the conducting line of action. Specialization is thus one of the contemporary resources for the complexity of knowledge in theoretical and practical field, and it must be seen within the principles of complementarity of knowing which does not necessarily represent fragmentation of care. 


\section{REFERENCES}

1. Barbosa SFF. A transcendência do emaranhado tecnológico em cuidados intensivos: a (re)invenção possível. Blumenau: Nova Letra; 1999.

2. Andrade LFS. A complexidade do cuidado de Enfermagem no CETIP/HSE e a necessidade da formação especializada dos enfermeiros. [Dissertação de Mestrado]. Rio de Janeiro (RJ): Escola de Enfermagem Anna Nery/UFRJ; 1999.

3. Benner P. From novice to expert: excellent and power in clinical nursing practice. California: Addison Wesley; 1984.

4. Espírito Santo FH. Saberes e fazeres de enfermeiras novatas e veteranas sobre o cuidado de enfermagem no cenário hospitalar. [Tese de Doutorado]. Rio de Janeiro (RJ): Escola de Enfermagem Anna Nery/UFRJ; 2003.

5. Mesquita AF, Souza CA, Souza SR. Avanços na qualidade do cuidado de Enfermagem na Terapia intensiva. Rev. Enfermagem Atual 2004 mar-abr; 20(4): 9-13.
6. Valadares GV, Viana LO. A globalização, as formas de organização do trabalho e a enfermagem. Esc. Anna Nery Rev. Enfermagem 2005 abril; 9(1): 116-23.

7. Santos BS. Um discurso sobre as ciências. São Paulo (SP): Cortez; 2006.

8. Silva AL, Ciampone MHT. Um olhar paradigmático sobre a assistência de enfermagem: um caminhar para o cuidado complexo. Rev. Esc. Enfermagem USP 2003; 37(4): 13-23. 9. Santos BS. Introdução a uma ciência pós-moderna. Rio de Janeiro (RJ): Edições Graal Ltda; 1989.

10. Weil P. O novo paradigma holístico - ondas a procura do mar. In: Weil P. O novo paradigma holístico. São Paulo (SP): Summus Editorial; 1993.

11. Capra F. O ponto de mutação. São Paulo (SP): Cultrix; 1993.

12. Carper BA. Fundamental patterns of knowing in nursing. ANS 1978; 1(1): 13-23. 